INTERDISCIPLINARIA ARCHAEOLOGICA

\title{
Investigation of Mass Graves in the Churchyard of St. Gertrude's, Riga, Latvia
}

\author{
Vita Rudovica $^{a^{*}}$, Arturs Viksna ${ }^{a}$, Andris Actins ${ }^{\mathrm{a}}$, Gunita Zarina ${ }^{\mathrm{b}}$, Guntis Gerhards $^{\mathrm{b}}$, Martins Lusens ${ }^{\mathrm{c}}$ \\ ${ }^{a}$ Department of Chemistry, the University of Latvia, Kr. Valdemara street 48, Riga, Latvia \\ ${ }^{b}$ Institute of Latvian History, the University of Latvia, Akademijas Laukums 1, Riga, Latvia \\ 'Architectural Research Group, Arsenala 3, Riga, Latvia
}

\section{ARTICLE INFO:}

\section{Article history:}

Received: 23 March 2011

Accepted: 17 May 2011

\section{Keywords:}

Riga

$16^{\text {th }}-17^{\text {th }}$ century

mass grave

bioarchaeology

soil analysis

dolomite

limestone

\begin{abstract}
A B S TR A C T
In late autumn 2006 archaeological excavations were undertaken in St. Gertrude's churchyard in Riga. 719 burials including two mass graves were uncovered. The most extensive use of the cemetery was during the $16^{\text {th }}$ to $17^{\text {th }}$ centuries. Anthropological analysis determined that inhumations in the mass graves might contain inhabitants of Riga or refugees who had died from disease and/or famine. Analysis of soil mineralogical composition indicated that dolomite limestone $\left(\mathrm{CaMg}\left(\mathrm{CO}_{3}\right)_{2}\right)$ was probably used to disinfect the bodies of epidemic victims in one of investigated mass graves.
\end{abstract}

\section{Introduction}

Burials were discovered between August and October 2006 during new housing development. Judging from the position of the bodies, the restricted space of the burials, the differences in graves soil texture, colour and other features, archaeologists determined these burials as mass graves (Jessee, Skinner 2005; Skinner et al. 2003; Tuller, Duric 2006). Preliminary observations led to the conclusion that these graves dated to the late $16^{\text {th }}$ and early $17^{\text {th }}$ century.

It should be mentioned that a relatively small number of mass graves in Latvia are dated back to this period. A number of military activities took place in Latvian territory at this time, such as the Livonian War (1558-1583), the Polish-Swedish

\footnotetext{
*Corresponding author. E-mail: witaaa@gmail.com
}

War (1600-1629), the Russo-Swedish War (1656-1661) and the Great Northern War (1700-1721). Military conflicts are often accompanied by crop failure and famine, followed by diseases and epidemics, leading to increased mortality of the population (Gerhards 2008). Some chronicles also reflect the situation of famine and diseases in the $16^{\text {th }}$ century. Franca Nienstedes and Johana Baedeker's chronicles provide information about the famine in Livonia in 1601 and 1602 followed by a plague epidemic in 1602 . F. Nienstede notes that many of Vidzeme's inhabitants moved to Riga to find food. Bodekers Chronicle mentions the plague of 1623 in Riga, where many thousands died (Lūsēns 2007).

Several hypotheses were considered. It was thought that the mass graves might contain inhabitants of Riga, or refugees, who had died from infections and/or famine or by mass execution during one of above mentioned wars.

The intention of this paper is to provide an anthropological evaluation of the mass graves, including chemical analysis of the soil in order to establish the possible use of disinfectants. 


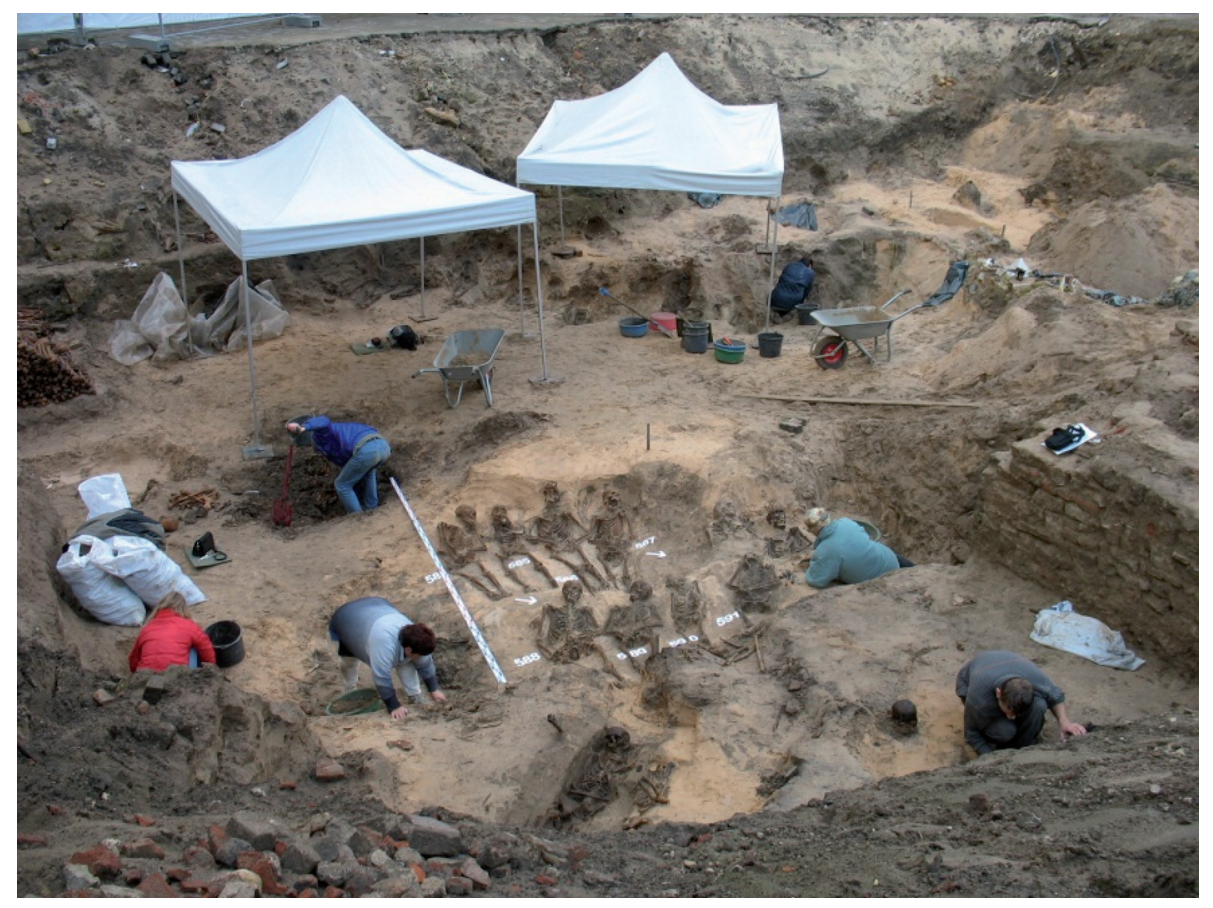

Figure 1. Excavation site.

\section{Methods}

\subsection{Site description}

The excavation site at 42/44 Brivibas street in Riga (Figure 1) is now within the modern Riga city centre. According to ancient maps this area was outside the city walls, in the North part of the St. Gertrude churchyard. The churchyard had been used as a cemetery from the $15^{\text {th }}$ century, most extensively during the $16^{\text {th }}$ to $17^{\text {th }}$ centuries. $200 \mathrm{~m}^{2}$ of the cemetery was excavated to a depth of $2.5-4.5 \mathrm{~m}$ below the current street level, and uncovered 709 burials containing a total of 719 individuals.

The limited area of the cemetery caused an increasing density of burials over time. Six layers of burials have been found, including two mass graves were found. In the north-western mass grave 120 individuals had been buried together in seven or eight layers in a ditch up to $2 \mathrm{~m}$ deep and $8 \mathrm{~m}$ long (Figure 2). In the lower layers the burials had been placed close together, sometimes with the bodies turned on the side, so that a larger number could be accommodated within the restricted space. Such considerations also explain the unusual placement of bodies in the upper layers of the fill of the trench. Here, all the dead of one layer had been placed on an incline with their heads pointed downwards, towards the middle of the ditch, their legs resting against its eastern side. In the following layer the bodies had been deposited in a reclining position, their upper bodies supported against the western side of the ditch. This kind of alternating positioning was used for several successive layers of burials.

In the south-east mass grave a total of 163 individuals were found in eight layers in a trench up to $3 \mathrm{~m}$ deep and 11 m long (Figure 3).

A part of the burials at the uppermost layers was destroyed by later burials. In the southern part of this mass grave, the bodies had been placed side by side in two rows, while in the northern part the burials were in a single row. In the upper layers the burials were also placed in a reclining position, their backs resting against the side of the ditch. However, comparatively few individuals had been buried in this manner. Evidently, the south-eastern mass grave had been dug sufficiently deep, so there was no need to save space.

According to the Christian tradition in Latvia, most of the buried in the St. Gertrude churchyard are placed with the head in a west-southwest direction. The absolute majority are supine. Wooden coffins were used in most individual burials (but generally not in mass graves).

Grave goods such as coins, ornamentations, tools and garment accessories were found only in 115 burials (approximately $16.2 \%$ of the total number). Few burials in the mass graves contained objects, such as coins (turn of the $16^{\text {th }}$ to $17^{\text {th }}$ centuries), different fibulae used for shirt fastening, or rings.

During excavation differences in soil colour and texture were found between the north-west mass grave and most other burials. Soil samples were collected to perform the soil chemical analysis.

\subsection{Methodology}

\subsubsection{Age and sex determination}

The subadult skeletal material was assessed for age using dental development (Ubelaker 1989), ossification and epiphyseal fusion (Scheuer et al. 2004), supported by long bone length (Šereikiene 2004). The main techniques used on the adult material were age-related pubic symphysis (Brooks, Suchey 1990), iliac auricular surface (Lovejoy et al. 1985), and sternal rib-end morphology (Iscan et al. 1984). 


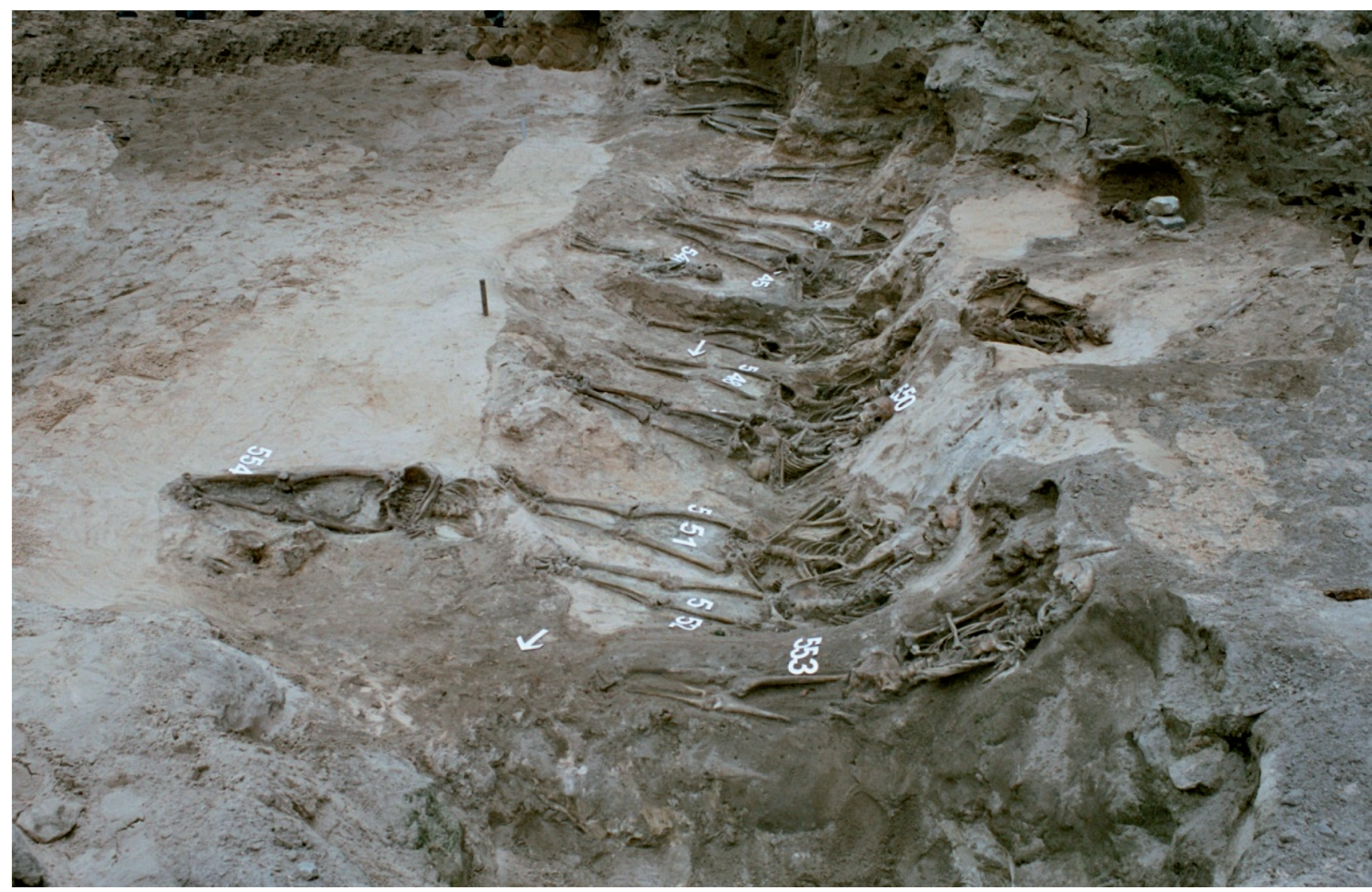

Figure 2. The north-west mass grave.

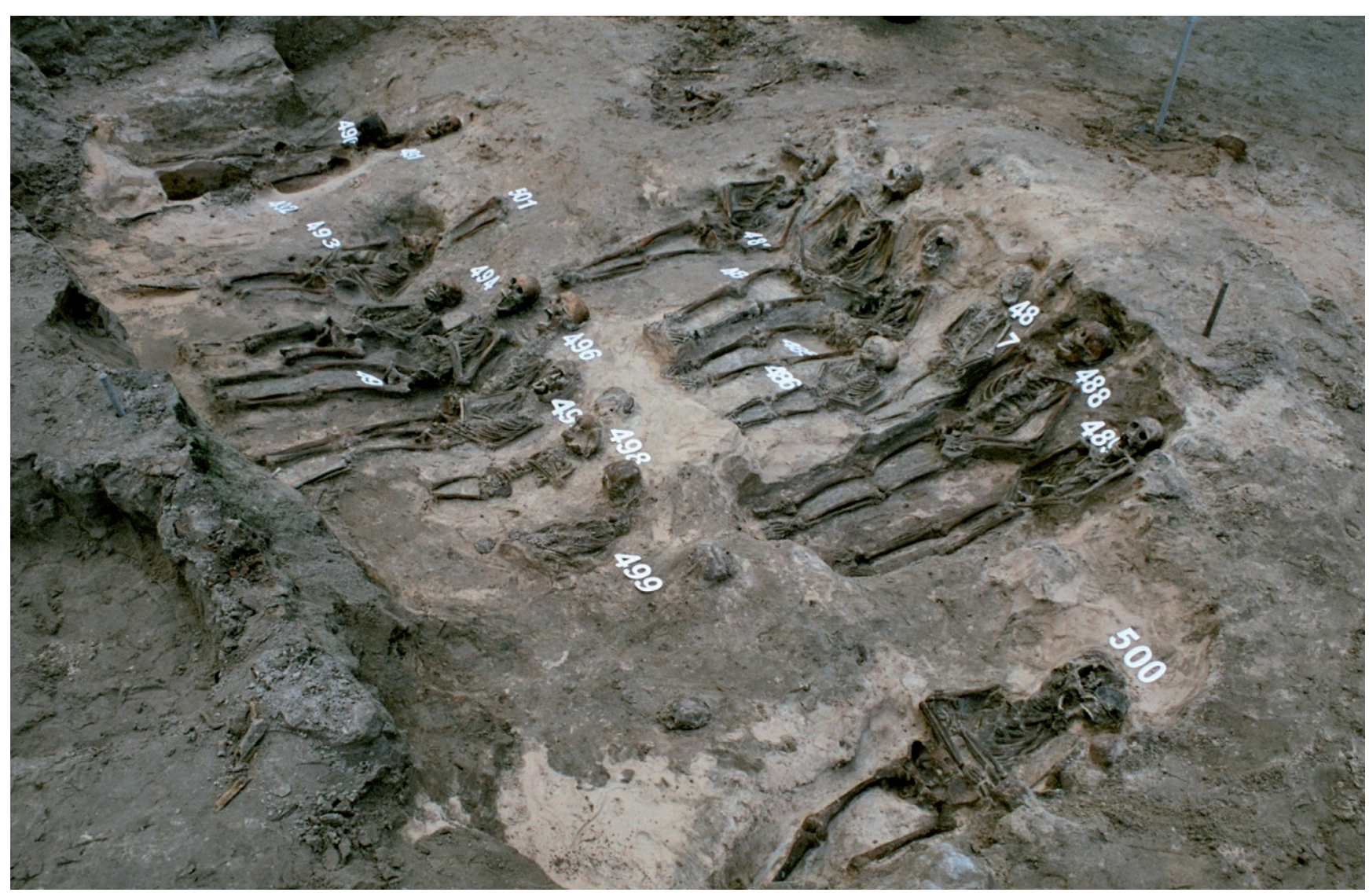

Figure 3. The south-east mass grave. 


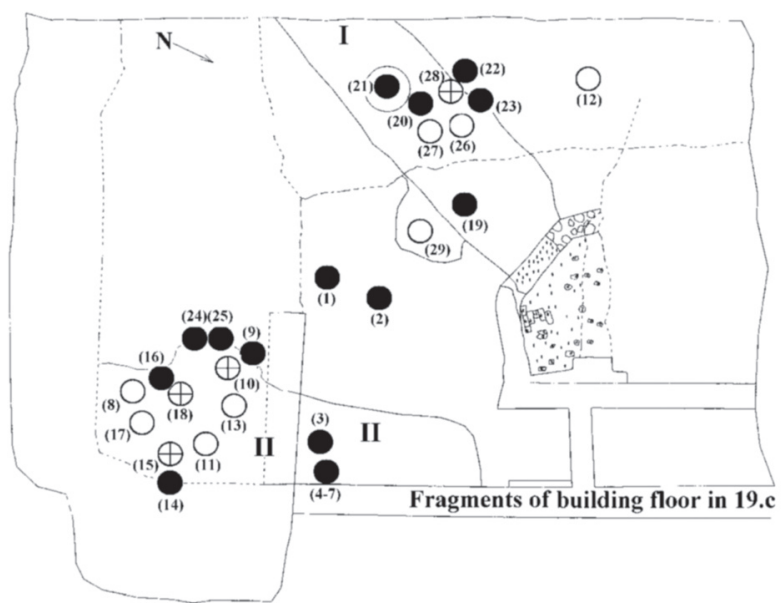

Figure 4. Soil sampling locations on the Brivibas street site: North-Western (I) and South-Eastern (II) groups. I - North-West mass grave; II - SouthEast mass grave; $\bullet$ - soil sample outside grave; o - soil sample inside grave; $\oplus$ - soil sample under bone.

\subsubsection{Palaeopathological study}

The osteological material was studied by the macroscopic investigation methods using an internationally accepted methodology (Ortner, Putschar 1985; Ortner 2005).

\subsubsection{Soil analysis}

$\mathrm{X}$-ray diffraction (XRD) was used for the identification of soil chemical composition (Pansu, Gautheyrou 2006; Pollard et al. 2007). A total of 29 soil samples each weighing about $500 \mathrm{~g}$ were taken across a total area of more than $200 \mathrm{~m}^{2}$ (Figure 4).

The soil was air dried at $40{ }^{\circ} \mathrm{C}$ in a drying oven until constant weight. The samples were mixed manually. Leaves, twigs and other coarse debris were removed using a $2 \mathrm{~mm}$ sieve, after which each sample was ground and homogenised with a mortar. This soil was extracted with a $1 \mathrm{M} \mathrm{KCl}$ solution at $20{ }^{\circ} \mathrm{C}$. The $\mathrm{pH}$ was measured in the settling suspension after shaking for 2 hours (Ranst et al. 1999). Additionally, soil samples were homogenized and passed through a $67 \mu \mathrm{m}$ sieve for structural analysis (Alam et al. 2007).

$\mathrm{X}$-ray powder diffraction was used to analyse soil chemical structure. The powder X-ray diffractometer (Bruker Advance D8), with a $\mathrm{Cu} \mathrm{K} \mathrm{K}_{\alpha} \mathrm{X}$-ray source $(\lambda=1.540,56 \AA)$ and a scintillation counter as the detector was operated at $40 \mathrm{kV}$ and $40 \mathrm{~mA}$. Each sample was scanned from 3 to $50^{\circ}$ $2 \theta$ in $0.02^{\circ}$ step.

\section{Results and discussion}

\subsection{Demography of burials}

Age and sex were determined for 641 individuals (89.3\% of burials). Palaeodemographical indices show an even sex ratio within the cemetery, as a whole and for the mass graves (Figure 5), excluding the possibility that mass graves might contain soldiers, killed in battle.

A comparison of the age structure of the cemetery and mass graves (Figure 6) indicates a substantially larger (by $20.7 \%$ ) proportion of children (aged $0-4$ ) in the cemetery. In the mass graves there are only 7 infant (aged 0-1) and 13 children (aged 1-4). In addition, $46.8 \%$ of mass grave burials are between $15-35$, compared to $27.6 \%$ in the cemetery. An especially high number of youths aged 15-17 (25.8\%) are found in the SE mass grave. The proportion of older individuals (aged $40-70$ ), at $21.9 \%$ of the grave population, is similar in the cemetery and mass graves.

In general, the age distribution of the mass graves with their high number of adolescents is close to a catastrophic death assemblage, whereas the cemetery burials have an ordinary mortality distribution with a high number of children and elderly (Gowland, Chamberlain 2005; Margerison, Knüsel 2002).

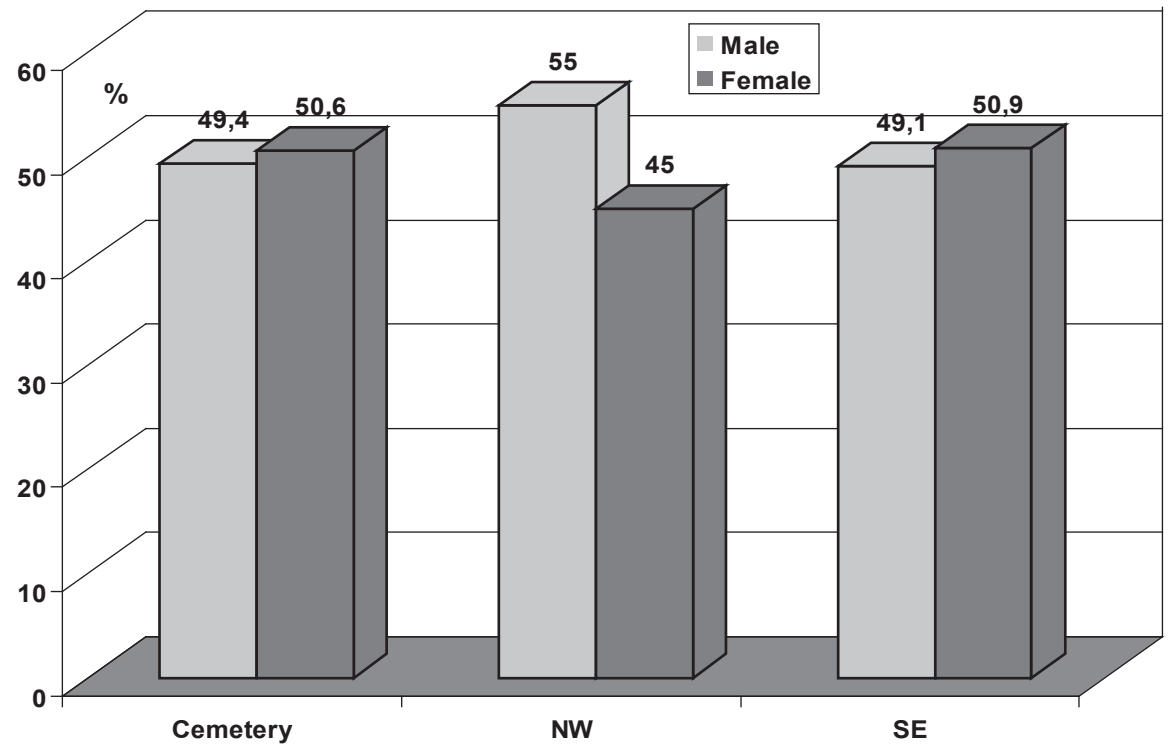

Figure 5. Statistical proportion of male and female burials in cemetery and in NW and $\mathrm{SE}$ mass graves. 
Figure 6. Distribution of mortality in the cemetery and NW, SE mass graves.

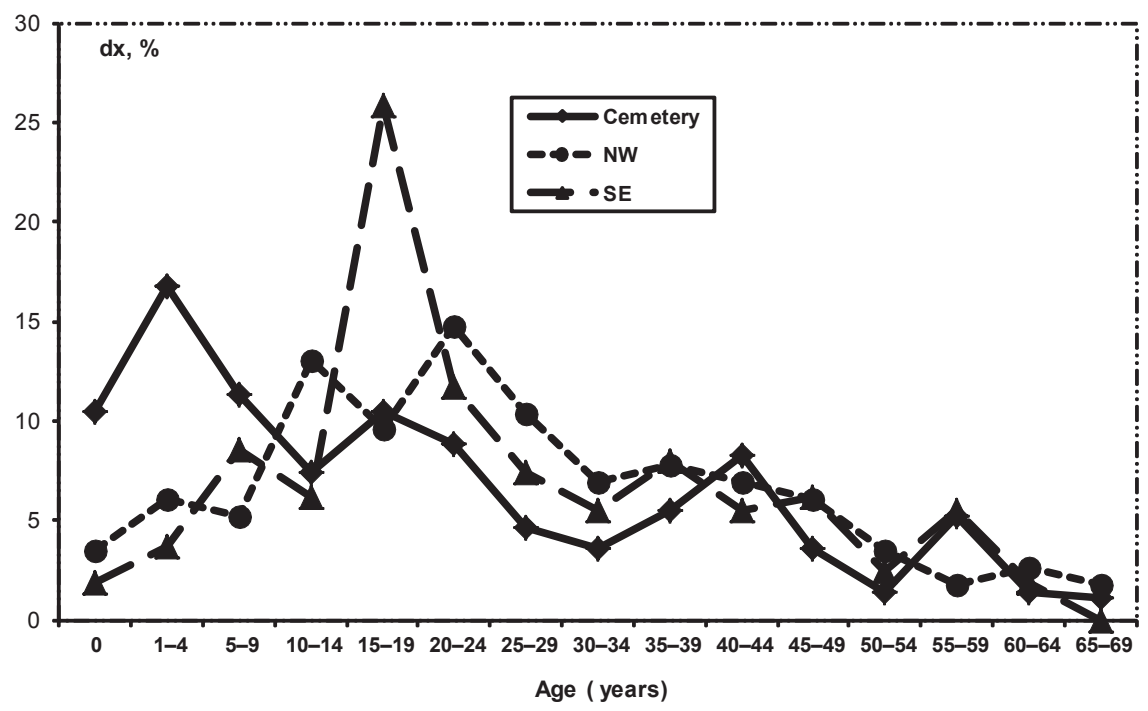

\subsection{Palaeopahological aspects of burials}

Palaeopahological investigation identified skeletal evidence of trauma in adults of both sexes, within both mass graves and the rest of cemetery. Traumatic lesions (antemortem) are numerous for males in the mass graves (29.4\%), but there are no cases where these traumas might be the cause of death. All cranial fractures in mass graves ( 7 individuals) were healed depression fractures with smooth margins and slightly porous floors. None penetrated the inner table of the skull or exhibited evidence of subsequent infection. Traumas to the left side of the frontal and parietal bones of the skull predominate. Fractures on the midshaft of the ulna were of particular interest. These fractures are considered defensive fractures and occur when an individual covers the face or head with the arm in an attempt to protect themselves from an assailant. There are no significant differences between midshaft ulna fracture frequencies in men in the mass grave $(11.8 \%)$ and cemetery $(12.1 \%)$ series.

Only 10 cases of violence (perimortem trauma) were detected in the rest of cemetery. All were adult males aged 20-35 years ( 7 cases with unhealed bone lesions, 3 cases with lead bullets). Archaeological artefacts (coins) indicate that the majority of those cases are attributable to the period 1656 - 1660, possibly during the Russo - Swedish War of 1656-1661 when the Russian army besieged Riga.

Some infectious diseases (e.g. tuberculosis, leprosy, and trepanematosis) often do leave specific lesions on bones.
It should be noted that only 5 cases of tuberculosis were detected (all in the mass graves). Cases of infection could be confirmed through further DNA analysis of M. tuberculosis.

Traces of periosteal reactions are unspecific markers of stress and deprivation, usually associated with inflammation. In our case a whole range of periosteal lesions were found from acute to chronic and healed. They were absent among subadults (possibly due to lethal outcome). On the other hand, two thirds of adults had periostical lesions. There were no differences between mass graves $(68.3 \%)$ and cemetery $(66.1 \%)$ nor between male and female.

\subsection{Soil analysis}

Soil $\mathrm{pH}(\mathrm{KCl})$ findings indicate that the soil in the SE mass grave was more acidic than the soil in the NW mass grave. For the site as a whole, soil $\mathrm{pH}$ ranged on average from 3.4 to 7.0. The soil samples from the NW area had a relatively high $\mathrm{pH}$ (between $\mathrm{pH}$ 5.8-6.7), while the $\mathrm{pH}$ values in the SE area were from 3.4 to 4.2 .

Semi-quantitative analysis of the soil diffractograms was undertaken using the "Difrac-plus Basic Evaluation Package EVA12" program. Table 1 shows the mineral content (\%) in the sampled soils.

Soil investigated outside the mass graves mainly was sandy (see Table 1). The basic mineralogical composition of this soil was: quartz $72 \%$, feldspars $23 \%$, muscovite $3 \%$ and traces of clay minerals, hornblendes and kaolinite.

Table 1. Semi-quantitative determination of soil chemical composition (\%) using X-ray powder diffraction; “-” no indication of peaks; “+” weak reflexes $(<2 \%)$.

\begin{tabular}{|c|c|c|c|c|c|c|c|c|c|}
\hline Averaged Sample & Clay & $\mathrm{SiO}_{2}$ & & $\begin{array}{l}\text { Irs } \\
\text { ase/ } \\
\text { ase }\end{array}$ & $\begin{array}{l}\text { Calcite } \\
\mathrm{CaCO}_{3}\end{array}$ & $\begin{array}{c}\text { Dolomite } \\
\mathrm{CaMg}\left(\mathrm{CO}_{3}\right)_{2}\end{array}$ & Muscovite & $\begin{array}{c}\text { Horn- } \\
\text { blendes }\end{array}$ & Kaolinite \\
\hline Outside graves (cemetery) & + & 72 & 9.5 & 14 & 0 & 0 & 2.8 & $\sim 0.5$ & $\sim 0.5$ \\
\hline Middle area (No. 1 and 2) & - & 8 & 2 & 2.0 & 15 & 71 & 1 & $\sim 0.5$ & $\sim 0.5$ \\
\hline Inside grave $N W$ area & + & 32 & 7 & 12 & 6 & 36 & 3.0 & 6 & 0.5 \\
\hline Inside grave $S E$ area & + & 49 & 19 & 24 & 0 & 0 & 6 & $\sim 1$ & $\sim 0.5$ \\
\hline
\end{tabular}




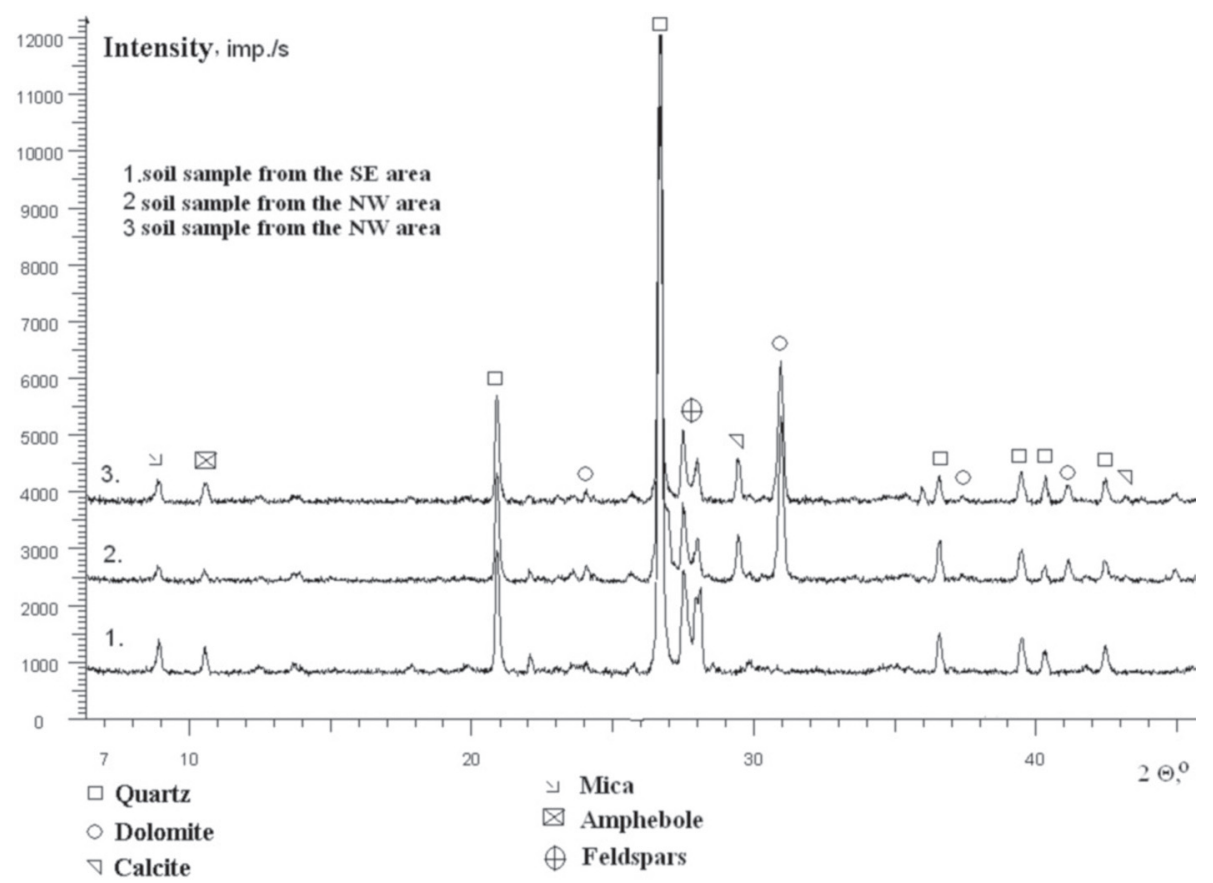

Figure 7. Comparison between X-ray powder diffraction patterns of soil samples from the mass graves. Only the main reflexes are shown. Based on the historical record two hypothesis were considered.
The same basic mineral composition of soil was also observed in both mass grave areas. The intensity of feldspar diffraction peaks were similar in all measured diffractograms and indicate soil homogeneity across the whole site.

As seen from the X-ray powder diffraction patterns, the quantitative content of soil inside the NW mass grave was different from the SE mass grave, (Figure 7). In the NW area additional calcite and dolomite minerals were observed (strong diffraction peaks of dolomite are at around $31.0^{\circ} 2 \theta$ and calcite at around $29.5^{\circ} 2 \theta$ ).

Dolomite and calcite content in the soil outside the NW mass grave (soil samples No. 1. and 2; see Fig. 4) was about two times larger than in the soil inside NW mass grave. The total amount of dolomite and calcite in the soil outside NW mass grave was $86 \%$ (Table 1) and without clay traces. These minerals (dolomite with calcite) are likely not of local origin.

\subsubsection{First hypothesis discussion}

Limestone and its derivatives, including quicklime (calcium oxide), slacked lime (calcium hydroxide) and dolomite (calcium and magnesium carbonate), are the oldest forms of chemistry known to humans. Limestone has been used since the Stone Age, although primitive humans probably found uses for it before that time. The first records relate to the Egyptian Second Dynasty (c. 5800 years ago), when it was employed in the construction of the Giza Pyramids. Over the centuries, limestone has been used extensively as an aggregate in building and construction. During the 1400s, the use of lime in building spread throughout Europe (Oates, 1998). St. Gertrude's Church had been burned several times over many wars. The first time St Gertrude's church was mentioned was in the Kemerejas register in 1413 (Bulmerincq 1913) and in Riga's Legacy book in 1418 (Napiersky 1888).
From the historical records and documentaries we assume that St. Gertrude's Church was located approximately $1 \mathrm{~km}$ away from the Riga city walls, close to main trunk road Big Sandy way- for over 400 years. The outskirts of the city spread around the church along the road and the churchyard was mentioned for the first time in Legacy book in 1436. The army of Ivan the Terrible (Grozny) burned down the church in 1559. The church was rebuilt in 1589 (Straubergs 1937). In 1605 the church was burned down in the Polish -Swedish War and rebuilt again. The Russian army pillaged the church in 1656 (Dunsdorfs 1962). The third time the church was burned by Saxon army at the beginning of the Great North War in 1700. Rebuilding was initiated in 1779 but it was burned once again (fourth time) in 1812 by the French army. Then a wood preaching house was build using G. Rinka project. It served till 1864 when the brick walled church was built. As we can see, the church was rebuilt many times from wood material during $16^{\text {th }}-17^{\text {th }}$ century. During excavations and geological observation dolomite was not found naturally in the excavated area. It seems that dolomite was introduced manually for certain purposes from external sources. Chemical analysis of soil found dolomite and calcite only in the NW mass grave area and outside this mass grave. To dig a $2 \mathrm{~m}$ deep and $8 \mathrm{~m}$ long trench for storing building material for church construction seems unbelievable.

\subsubsection{Second hypothesis discussion}

In a burial environment a number of factors may inhibit bacterial growth, thus retarding decomposition and setting up favorable preservation conditions. Dolomite, or its burned products quicklime, slacked lime, or lime, was used as a disinfectant for the bodies of epidemic victims. Quicklime is rather aggressive chemical agent and may cause serious burns when in contact with the skin (Horacio 2007). When 
organic matter is added to burnt lime and water, the chemical reaction releases energy in the form of heat. Organic material is destroyed and odours eliminated. Historical records show that quicklime has been used in mass graves for hundreds of years to help prevent the spread of disease and eliminate odour.

Dolomite decomposition reaction proceeds between $700^{\circ} \mathrm{C}$ and $740-750^{\circ} \mathrm{C}$ as following:

$$
2 \mathrm{CaMg}\left(\mathrm{CO}_{3}\right)_{2} \rightarrow \mathrm{CaCO}_{3}+\mathrm{CaO}+2 \mathrm{MgO}+3 \mathrm{CO}_{2}
$$

At the higher temperature, the $\mathrm{CaCO}_{3}$ begins to decompose even though dolomite is still present (Engler et al. 1988; Gunasekaran, Anbalagan 2007). Thus, two reactions occur simultaneously at temperature above $800^{\circ} \mathrm{C}$ and summary reactions can be presented as following:

$$
\begin{gathered}
\mathrm{CaMg}\left(\mathrm{CO}_{3}\right)_{2} \rightarrow \mathrm{CaO}+\mathrm{MgO}+2 \mathrm{CO}_{2} \\
\mathrm{CaCO}_{3} \rightarrow \mathrm{CaO}+\mathrm{CO}_{2}
\end{gathered}
$$

Dolomite $\left.\left(\mathrm{CaMgCO}_{3}\right)_{2}\right)$ burns to form quicklime $(\mathrm{CaO}$ $\mathrm{MgO}$ ). The system in the soil $\mathrm{MgO}-\mathrm{CaO}-\mathrm{H}_{2} \mathrm{O}-\mathrm{CO}_{2}$ is complicated. Hydrated lime $\left(\mathrm{Ca}(\mathrm{OH})_{2}\right.$ and $\left.\mathrm{Mg}(\mathrm{OH})_{2}\right)$ then can be produced by adding water to the quicklime. The magnesium oxide component of dolomite quicklime requires elevated pressure or long slacking periods to hydrate completely. The burial environment is subject to local elevated pressure and temperature (or hydrothermal conditions) and this system is in contact with water (rainwater). So briefly formed system $\mathrm{CaO}, \mathrm{Ca}(\mathrm{OH})_{2}, \mathrm{MgO}$ and $\mathrm{Mg}(\mathrm{OH})_{2}$ reacts with $\mathrm{CO}_{2}$ to form $\mathrm{CaCO}_{3}$ or $\mathrm{MgCO}_{3}$ and to convert it back to dolomite (Chesworth 2008; Johnson 2002).

Complexity is seen to arise when dealing with dolomite which is believed to cause a change in crystallography and microstructure. The peak position displacement due to solid solution formation over time was not observed. It is a bit surprising and casts doubt about a complete dolomite cycle. So the hypotheses of the use of quicklime as a disinfection material seems to also be invalid.

\section{Conclusions}

The general lack of pathology and trauma among mass grave skeletons, combined with demographic, archaeological and historical data, suggests that both mass graves held victims of epidemic, infections and/or famine. The great majority of skeletons were anatomically undisturbed, clearly indicating that they had been buried in a fairly short space of time, or even on a single occasion. None of these individuals had osteological indications of violent death. It is expected that in these mass graves were buried people not only from the vicinity of Outer Riga, but also from a larger area (Vidzeme), who had congregated in the vicinity of the city in $1601-1602$ (a year of famine and diseases) or during the 1623 plague.

Soil analysis identified a dolomite mixture with calcite (dolomite limestone) from one of the mass grave.
Work on the material of this site is still in progress. DNA analysis is planned to identify pathogens (e.g. Yersinia pestis). A few radiocarbon dates of skeletons from each section will provide a much better chronological framework.

\section{Acknowledgements}

This work has been supported by the European Social Fund within the project "Support for Doctoral Studies at University of Latvia".

\section{References}

ALAM, A. K. M. M., XIE, S., SAHA, D. K., CHOWDHURY, S. Q. 2008 : Clay mineralogy of archaeological soil: An approach to paleoclimatic and environmental reconstruction of the archaeological sites of the Paharpur area, Badalgacchi upazila, Naogaon district, Bangladesh. Environmental Geology 53 (8), 1639-1650.

BROOKS, S. T., SUCHEY, J. M. 1990: Skeletal age determination based on the os pubis: a comparison of the Ascádi-Neméskeri and Suchey-Brooks methods. Journal of Human Evolution 5 (3), 227-238.

BULMERINCQ, A. 1913: Kammerei-Register der Stadt Riga 1348-1361 und 1404-1474. Leipzig.

Encyclopedia of Soil Science. Chesworth, W. (Ed.), Berlin, 2008.

DUNSDORFS, E. 1962: Latvijas vēsture 1600-1710. Stokholma, Zviedrija.

ENGLER, P., SANTANA, M. W., MITTLEMAN, M. L., BALAZS, D. 1988 : Non - Isothermal. In Situ XRD Analysis of Dolomite Decomposition. The Rigaku Journal 5 (2), 3-8.

GERHARDS, G. 2008: Masu apbedījumi Sēlpils viduslaiku kapsētā. Latvijas Vēstures Institūta Žurnāls 4, 20-39.

GOWLAND, R. L., CHAMBERLAIN, A. T. 2005: Detecting plague: palaeodemographic characterisation of a catastrophic death assemblage. Antiquity 79, 146-157.

GUNASEKARAN, S., ANBALAGAN, G. 2007: Thermal decomposition of natural dolomite. Bulletin of Materials Science 30 (4), 339-344.

HORACIO, E. S. 2007: Quicklime and caustic soda water effects on a fresh cadaver. The Forensic Examiner 16 (2), 10-22.

ISCAN, M. Y., LOTH, S. R., WRIGHT, R. K. 1984: Age estimation from the rib by phase analysis: white males. Journal of Forensic Sciences 29 (4), 1094-1104.

JESSEE, E., SKINNER, M. 2005: A typology of mass grave and mass grave-related sites. Forensic Science International 152 (1), 55-59.

JOHNSON, D (ed.) 2002: Metals and Chemical Change. Cambridge.

LOVEJOY, C. O., MEINDL, R. S., PRYZBECK, T. R., MENSFORTH, R. P. 1985: Chronological metamorphosis of the auricular surface of the ilium: a new method for the determination of adult skeletal age at death. American Journal of Physical Anthropology 68 (1), 15-28.

LŪSĒNS, M. 2007: Arheologiskie pētījumi Sv. Ģertrūdes baznīcas kapsētā Rīgā. Arheologu pētījumi Latvijā 2006. un 2007. gadā, 143-151.

MARGERISON, B. J., KNÜSEL, C. J. 2002: Paleodemographic comparison of a catastrophic and an attritional death assemblage. American Journal of Physical Anthropology 119 (2), 134-143.

NAPIERSKY, J. G. L. 1888: Die Erbebücher der Stadt Riga 1384-1597. Riga, Latvia.

OATES, J. A. H.1998: Lime and Limestone: Chemistry and Technology, Production and Uses. Wiley - VCH Verlag GmbH, Weinheim.

ORTNER, D. J., PUTSCHAR, W. G. J. 1985: Identification of Pathological Conditions in Human Skeletal Remains. Smithsonian Institution Press, Washington DC.

ORTNER, D. J. 2005: Identification of Pathological Conditions in Human Skeletal Remains. Second ed. Academic Press, Washington.

PANSU, M., GAUTHEYROU, J. 2006: Handbook of Soil Analysis: Mineralogical, Organic and Inorganic Methods. Springer, Berlin. 
POLLARD, A. M., BATT, C. M., STERN, B., YOUNG, S. M. M. 2007: Analytical Chemistry in Archaeology. Cambridge University Press, Cambridge.

RANST, E. V., VERLOO, M., DEMEYER, A., PAUWELS, J. M. 1999: Manual for the soil Chemistry and Fertility Laboratory. Ghent University, Ghent.

SCHEUER, L., BLACK, S. 2004: The Juvenile skeleton. Elsevier, London. SKINNER, M., ALEMPIJEVIC, D., DJURIC - SREJIC, M. 2003 Guidelines for International Forensic Bio-archaeology Monitors of Mass Grave Exhumations. Forensic Science International 134 (2-3), 81-92.

STRAUBERGS, J. 1937: Rīgas vēsture. Rīga.
ŠEREIKIENÉ, J. 2004: Skeleto augimo ypatumai Lietuvos paleoosteologines medžiagos duomenimis. Daktaro disertacija. Išduota: Medicinos fakulteto biblioteka, Vilniaus Universitetas, Vilnius.

TULLER, H., ĐURIC, M. 2006: Keeping the pieces together: Comparison of mass grave excavation methodology. Forensic Science International 156 (2), 192-200.

UBELAKER, D. H. 1989: Human skeletal remains. Excavation, Analysis, Interpretation. Second ed. Aldine Press, Taraxacum. 